\title{
27. OCCURRENCE AND ORIGIN OF ANHYDRITE FROM DEEP SEA DRILLING PROJECT LEG 70, HOLE 504B, COSTA RICA RIFT ${ }^{1}$
}

J. C. Alt and J. Honnorez, Rosenstiel School of Marine and Atmospheric Science, University of Miami, Miami, Florida

H.-W. Hubberten, ${ }^{2}$ Institut für Petrographie und Geochemie der Universität Karlsruhe, D-75 Karlsruhe 1, Federal Republic of Germany

and

E. Saltzman, Rosenstiel School of Marine and Atmospheric Science, University of Miami, Miami, Florida

\begin{abstract}
The first anhydrite reported from oceanic basalts occurs in altered basalts drilled during DSDP Leg 70 from Hole 504B. Anhydrite has been identified in several samples, two of which were studied in detail.

Anhydrite in Sample 504B-40-3 $(130-135 \mathrm{~cm})$, which was acquired at 310 meters sub-basement, occurs in a dolerite at the center of a vug rimmed by saponite and calcite. Red iron-hydroxide-rich alteration halos occur from 0 to 310 meters sub-basement; primary sulfides in these halos are oxidized, and the rocks have lost large amounts of sulfur. The anhydrite in this sample has a $\delta^{34} \mathrm{~S}$ value of $18.5 \%$, and it is interpreted to have formed from a fluid containing a mixture of seawater sulfate $(20.9 \%$ ) and basaltic sulfur $(0 \%$ ) released during the oxidation of primary sulfides.

Anhydrite in Sample 504B-48-3 (14-18 cm), which was found at 376 meters sub-basement, occurs intergrown with gyrolite at the center of a 1-cm-wide vein that is rimmed by saponite and quartz. At sub-basement depths below 310 meters to the bottom of the Leg 70 section ( $562 \mathrm{~m}$ sub-basement), the rocks exhibit the effects of anoxic alteration with common secondary pyrite. Anhydrite in Sample 504B-48-3 $(14-18 \mathrm{~cm})$ has a $\delta^{34} \mathrm{~S}$ value of $36.7 \%$, and it is interpreted to have formed from seawater-derived fluids enriched in ${ }^{34} \mathrm{~S}$ through sulfate reduction. Temperatures of alteration calculated from oxygen isotope data range from 60 to $100^{\circ} \mathrm{C}$. Sulfate reduction may have occurred in situ, or elsewhere at higher temperature, possibly deeper in the crust.

The secondary mineral paragenetic sequence indicates a progressive decrease in $\mathrm{Mg}$ and increase in $\mathrm{Ca}$ in the circulating fluids. This eventually led to anhydrite formation late in the alteration process.
\end{abstract}

\section{INTRODUCTION}

The presence of anhydrite in the oceanic crust has long been suspected. Anhydrite formation has been observed in several experimental studies of basalt/seawater interaction at elevated temperatures (Bischoff and Dickson, 1975; Mottl, 1976; Seyfried, 1977; Seyfried et al., 1978; Bischoff and Seyfried, 1978). It has also been found in drill holes in the Reykjanes geothermal system in Iceland (Tómasson and Kristmannsdottir, 1972). Drever et al. (1979) found gypsum in a vein in basalts from DSDP Leg 45 and suggested that the gypsum formed by the replacement of anhydrite, which formed at higher temperature. More recently, anhydrite has been found associated with hydrothermal activity at $21^{\circ} \mathrm{N}$ on the East Pacific Rise (Haymon and Kastner, 1981; Styrt et al., 1981). The complete absence of anhydrite in both drilled and dredged rocks from the seafloor has been puzzling and difficult to explain.

Hole 504B at the Costa Rica Ridge contains the first occurrence of anhydrite in Layer 2 of the oceanic crust. This report presents preliminary petrographic and isotopic evidence for the origin of this anhydrite.

\footnotetext{
${ }^{1}$ Cann, J. R., Langseth, M. G., Honnorez, J., Von Herzen, R. P., White, S. M., et al. Init. Repts. DSDP, 69: Washington (U.S. Govt. Printing Office).

2 Present address: Inst. de Geología, Universidad Autónoma de Nuevo Leon, 67700 Linares, N. L., Mexico.
}

\section{ANHYDRITE IN HOLE 504B}

Anhydrite was identified by X-ray diffraction and optics in several veins from the lower portion of the hole, from 581 meters sub-bottom almost to the bottom of the hole drilled during Leg 70 .

We found anhydrite in Samples 504B-40-3 (130-135 $\mathrm{cm})$; 504B-43-2 (28-30 cm); 504B-48-3 (14-18 cm); 504B48-3 (43-47 cm); 504B-53-1 (3-5 cm); 504B-68-1 (12-14 $\mathrm{cm})$; and 504B-69-1 (95-99 cm). It was always accompanied by a green saponite (identified by X-ray diffraction).

Anhydrite was also found by X-ray diffraction in veins in Samples 504B-61-2 (145-148 cm); 504B-64-1 $(65-68 \mathrm{~cm})$; 504B-66-2 $(0-5 \mathrm{~cm})$; and 504B-68-1 (81-87 $\mathrm{cm}$ ), where it was often accompanied by quartz (Kurnosov et al., this volume).

In Sample 504B-40-3 (130-135 cm), anhydrite occurs in a large (about 1-cm-diameter) vug in a dolerite. Anhydrite is associated with two generations of calcite and a green trioctahedral smectite (060 spacing: 1.537 $\AA$ ). The adjacent rock contains trioctahedral smecite \pm calcite \pm iron hydroxides as pseudomorphs of olivine phenocrysts.

In Sample 504B-48-3 (14-18 cm), anhydrite occurs in a fine-grained basalt in a vein up to $5 \mathrm{~mm}$ thick (Plate 1). The mineral paragenesis from the walls of the vein to its center is as follows: (1) green trioctahedral smectite (060 spacing: $1.54 \AA$ ), forming a continuous $0.1-\mathrm{mm}$ thick border; (2) elongated quartz prisms (up to $0.5 \mathrm{~mm}$ 
in length), sometimes associated in radial groups; (3) occasionally a second generation of smectite; and (4) gyrolite sheafs, including large (up to 5-mm-long) euhedral tabular prisms of anhydrite. The latter are often bent or broken, with the fractures healed by anhydrite. The major part of the vein is made up of intergrown gyrolite and anhydrite.

\section{ANALYTICAL METHODS}

The sulfur isotope composition of Sample 504B-48-3 (14-18 cm) was measured in three different laboratories, each of which used different preparation techniques. One converted anhydrite to $\mathrm{H}_{2} \mathrm{~S}$ by using Thode's solution and from $\mathrm{H}_{2} \mathrm{~S}$ to $\mathrm{CdS}, \mathrm{Ag}_{2} \mathrm{~S}$, and finally $\mathrm{SF}_{6}$ by reaction with $\mathrm{BrF}_{5}$ (Thode and Rees, 1971). The second used reduction to $\mathrm{H}_{2} \mathrm{~S}$, conversion to $\mathrm{CdS}$, and oxidation to $\mathrm{SO}_{2}$ by reaction with $\mathrm{V}_{2} \mathrm{O}_{5}$ (Ricke, 1964). The third converted the sample to $\mathrm{BaSO}_{4}$ and then (by thermal decomposition) to $\mathrm{SO}_{2}$ (Holt and Engelkemeir, 1972; Bailey and Smith, 1972).

Sample 504B-40-3 $(130-135 \mathrm{~cm})$ was only analyzed once, as $\mathrm{SF}_{6}$, because of its small size.

The oxygen isotope composition of Sample 504B-48-3 (14-18 cm) was measured by using the graphite reduction technique (Sakai and Krouse, 1971; Mizutani, 1971). The anhydrite sample was dissolved in $\mathrm{HCl}$, passed through a cation exchange resin, and precipitated as $\mathrm{BaSO}_{4}$ by addition of $\mathrm{BaCl}_{2}$. The $\mathrm{BaSO}_{4}$ was mixed with graphite and heated under vacuum to $1100^{\circ}$ in a resistance-heated platinum boat. Any $\mathrm{CO}$ produced was converted to $\mathrm{CO}_{2}$ by disproportionation in a high voltage discharge between two platinum plates. The oxygen isotope composition of the $\mathrm{CO}_{2}$ produced was measured by mass spectrometry.

The isotope results for $\delta^{34} \mathrm{~S}$ are reported in relation to the Cañon Diablo Troilite (CDT) standard and for $\delta^{18} \mathrm{O}$ in relation to standard mean ocean water (SMOW) (Table 1).

The University of Karlsruhe received a different subsample of Sample 504B-48-3 $(14-18 \mathrm{~cm})$ from that analyzed by the other laboratories. The divergent value obtained for this sample may indicate isotope heterogeneity within the vein. However, this conclusion must be considered preliminary until a more rigorous interlaboratory comparison is undertaken. McMaster University and the University of Miami analyzed a single homogenized subsample of the anhydrite vein. Although the difference between the $\delta^{34} \mathrm{~S}$ values obtained is small $(0.5 \%)$, it is larger than would be expected from the precision of the analyses. The discrepancy probably stems from errors in the correction factors for oxygen isotope interference, which is inherent in measurements of $\delta^{34} \mathrm{~S}$ using $\mathrm{SO}_{2}$.

In the following discussion, the results obtained using $\mathrm{SF}_{6}$ will be used, because both anhydrite samples were analyzed by this technique and because a detailed study of the $\delta^{34} \mathrm{~S}$ of seawater sulfate was previously reported from the same laboratory (Rees, 1978).

\section{DISCUSSION}

The two anhydrite samples, although only 66 meters apart in the hole, exhibit strikingly different sulfur isotope compositions. Sample 504B-40-3 (130-135 cm),

Table 1. Sulfur and oxygen isotope results from two anhydrite samples recovered from Hole 504B. The estimated precision of each measurement is also listed.

\begin{tabular}{cccl}
\hline \multicolumn{1}{c}{ Sample } & $\delta^{34} \mathrm{~S}$ CDT & $\delta^{18} \mathrm{O}$ SMOW & \multicolumn{1}{c}{ Laboratory } \\
\hline $504 \mathrm{~B}-40-3(130-135 \mathrm{~cm})$ & $18.9 \pm 0.07$ & - & McMaster University $\mathrm{a}$ \\
$504 \mathrm{~B}-48-3(14-18 \mathrm{~cm})$ & $36.7 \pm 0.07$ & - & McMaster University $^{\mathrm{a}}$ \\
& $33.7 \pm 0.3$ & - & University of Karlsruhe $^{\mathrm{b}}$ \\
& $37.2 \pm 0.15$ & $20.6 \pm 0.3$ & University of Miami $^{\mathrm{c}}$ \\
\hline
\end{tabular}

a Hamilton, Ontario, Canada. Analysis performed by C. E. Rees.

b Karlsruhe, Germany. Analysis performed by H. Hubberten.

c Miami, Florida. Analysis performed by E. Saltzman. which is at a sub-basement depth of 310 meters $(584.5 \mathrm{~m}$ sub-bottom), has a $\delta^{34} \mathrm{~S}$ value of $18.9 \%$, and Sample 504B-48-3 (14-18 cm), which is at 376 meters sub-basement ( $650.5 \mathrm{~m}$ sub-bottom), has a $\delta^{34} \mathrm{~S}$ value of $36.7 \%$. The host rocks adjacent to the veins that contain these samples exhibit quite different alteration features: oxidative in the first case and more reducing in the second. The evidence suggests that different processes are responsible for the formation of the two anhydrites and that both processes involve extensive interaction between the altering fluids and the basaltic column.

The $\delta^{34} \mathrm{~S}$ value of Sample 504B-40-3 $(130-135 \mathrm{~cm})$ $\left(18.9 \%\right.$ ) is significantly lower than the $\delta^{34} \mathrm{~S}$ of seawater sulfate $(20.99 \pm 0.12 \%$; Rees, 1978$)$ Since both values were measured in the same laboratory and by the same technique $\left(\mathrm{SF}_{6}\right)$, the difference between them is real and not subject to the large uncertainties associated with interlaboratory comparisons (see Table 1 and Rees, 1978). These results suggest that the anhydrite precipitated from a solution containing a mixture of seawater sulfate and sulfate derived from the oxidation and release of primary basaltic sulfide sulfur. The alteration of the host rocks supports this idea. Iron-hydroxide-rich red alteration halos, of which Sample 504B-40-3 $(130-135 \mathrm{~cm})$ is the deepest example, occur to 310 meters sub-basement in Hole 504B. Primary sulfides in these halos are oxidized, and the bulk rocks have lost much sulfur relative to fresh submarine basalts (Hubberten, this volume). The anhydrite is interpreted as a late stage secondary mineral that formed after the sulfide oxidation and the development of the red halos. The isotope composition of the anhydrite indicates a ratio of basaltic $(0 \%)$ and seawater sulfur $(20.99 \%$ ) of roughly $1: 9$ in the circulating fluids.

The high $\delta^{34} \mathrm{~S}$ in Sample 504B-48-3 $(14-18 \mathrm{~cm})(36.7 \%$ ) is strong evidence that sulfate reduction occurred in the hydrothermal fluids prior to anhydrite precipitation. The presence of anhydrite indicates that sulfate reduction was not complete. This means that either the system did not reach equilibrium or that large water-to-rock ratios caused the extent of sulfate reduction to be limited by the availability of reduced iron. At equilibrium, solutions containing residual sulfate can only be produced at water-to-rock mass ratios in excess of 130:1, the point at which all available ferrous iron has been utilized by sulfate reduction.

Shanks et al. (1981) demonstrated that equilibrium sulfur isotope fractionation was obtained during experimental sulfate reduction. In their experiments, the sulfide produced was continuously removed from solution as pyrite and did not re-equilibrate with sulfate in solution. Under these conditions the $\delta^{34} \mathrm{~S}$ of the sulfate remaining in solution increases continuously during sulfate reduction, reaching values of greater than $35 \%$ after the reduction of only about $50 \%$ of the sulfate initially present.

The kinetic sulfur isotope fractionation during sulfate reduction is about $-10 \%$ at temperatures between 200 and $290^{\circ} \mathrm{C}$ (Grinenko et al., 1969). In this case, only the last traces of sulfate remaining in solution during sulfate reduction would approach $\delta^{34} \mathrm{~S}$ values as high as 
that observed. It is unlikely that enough heavy sulfate could be produced in this manner to form significant amounts of anhydrite.

The oxygen isotope composition of Sample 504B-48-3 $(14-18 \mathrm{~cm})$ is $20.6 \%$ relative to SMOW. This value yields a calculated temperature of 60 to $80^{\circ} \mathrm{C}$ (Chiba et al., 1981), assuming that the water from which the anhydrite precipitated had a $\delta^{18} \mathrm{O}$ between $0 \%_{0}$ and $-4 \%$, the value of the overlying sediment pore waters (Mottl, Lawrence, et al., this volume). This is in good agreement with the oxygen isotope temperature obtained from smectite in Sample 504B-48-3 (14-18 cm) $\left(60-100^{\circ} \mathrm{C}\right.$; Honnorez et al., this volume) and the downhole temperature where the sample occurs $\left(100^{\circ} \mathrm{C}\right)$.

No direct evidence exists to indicate that sulfate reduction occurred in the immediate vicinity of Sample 504B-48-3 (14-18 cm). Below 310 meters sub-basement ( $584.5 \mathrm{~m}$ sub-bottom), bulk rocks are slightly oxidized (Honnorez et al., this volume); however, this is probably due at least in part to the post-sampling oxidation of clay minerals (Andrews et al., this volume). Sulfur isotope data from vein pyrites is equivocal; it is consistent with the reduction of seawater sulfate or the remobilization of basaltic sulfur (Hubberten, this volume). Sulfate reduction has not been observed in experimental seawater basalt interactions below $200^{\circ} \mathrm{C}$ because the kinetics of sulfate reduction are sluggish at these temperatures (Shanks et al., 1981). Ohmoto and Lasaga (1980) calculated that equilibrium between sulfide and sulfate will occur within $1000 \mathrm{yr}$. in typical hydrothermal fluids $\left(\mathrm{pH}=4-6 ; \Sigma \mathrm{S}=10^{-2}-10^{-3} \mathrm{~m}\right.$ ) only at temperatures greater than $200^{\circ} \mathrm{C}$. However, this does not preclude sulfate reduction at lower temperature, such as that at which the anhydrite in Hole 504B formed, given sufficient time. Alternatively, sulfate reduction may have occurred deeper in the crust, where temperatures are significantly higher (Leg 83 Scientific Party, in press).

The paragenesis of secondary minerals in the Leg 70 section of Hole 504B generally indicates a change from the precipitation of $\mathrm{Mg}$-rich smectites to $\mathrm{Ca}$ - and $\mathrm{Na}$ rich zeolites and calcium carbonate with time (Honnorez et al., this volume). Plagioclase phenocrysts are commonly partly replaced by smectite in the lower part of the hole, and pore waters in the overlying sediments are enriched in $\mathrm{Ca}$ and depleted in $\mathrm{Mg}$ relative to seawater (Honnorez et al., this volume; Mottl, Lawrence, et al., this volume). This evidence documents a progressive increase in the $\mathrm{Ca}$ content of the circulating fluids. Although the two anhydrites derived their sulfur from different processes, they both appear as late stage vein minerals. In both cases anhydrite saturation was probably exceeded as a consequence of calcium release from the surrounding rocks under conditions similar to those presently occurring at Hole 504B.

\section{CONCLUSIONS}

1. Anhydrite in Sample 504B-40-3 (130-135 cm) has a $\delta^{34} \mathrm{~S}$ value of $18.9 \%$. This sample occurs in rocks that exhibit the effects of oxidative alteration, and it probably formed from solutions containing a mixture of seawater and basaltic sulfur.
2. Anhydrite in Sample 504B-48-3 (14-18 cm) has a $\delta^{34} \mathrm{~S}$ value of about $36 \%$, and it probably formed from seawater solutions enriched in $\delta^{34} \mathrm{~S}$ through sulfate reduction. This sample occurs in rocks that exhibit the effects of anoxic alteration; sulfate reduction may have occurred in situ or elsewhere, possibly deeper in the crust.

3. Secondary mineral parageneses indicate a progressive decrease in $\mathrm{Mg}$ and an increase in $\mathrm{Ca}$ in the circulating fluids. The resulting increase in the saturation of the fluids with respect to anhydrite led to its occurrence as a late stage vein-filling mineral.

\section{ACKNOWLEDGMENTS}

We wish to thank T. Ding and C. E. Rees for sulfur isotope analyses. We also thank D. Price for his analytical advice and A. Castellanos for his assistance in the laboratory. The manuscript benefited from reviews by G. W. Brass, C. G. A. Harrison, and H. D. Holland. This research was supported by NSF grant number OCE-8117698 to J. H. and a grant of the Deutsche Forschungsgemeinschaft, Bonn to $\mathrm{H}$. H. Contribution of the University of Miami.

\section{REFERENCES}

Bailey, S. A., and Smith, J. W., 1972. Improved method for the preparation of sulfur dioxide from barium sulfate for isotope ratio studies. Anal. Chem., 44:1542-1543.

Bischoff, J. L., and Dickson, F. W., 1975. Seawater-basalt interaction at $200^{\circ} \mathrm{C}$ and 500 bars: implications for origin of sea-floor heavy-metal deposits and regulation of seawater chemistry. Earth Planet. Sci. Lett., 25:385-397.

Bischoff, J. L., and Seyfried, W. E., 1978. Hydrothermal chemistry of seawater from $25^{\circ}$ to $350^{\circ} \mathrm{C}$. Am. J. Sci., 278:838-860.

Chiba, H., Kusakabe, M., Hirano, S., Matsuo, S., and Somiya, S., 1981. Oxygen isotope fractionation factors between anhydrite and water from 100 to $550^{\circ} \mathrm{C}$. Earth Planet. Sci. Lett., 53:55-62.

Drever, J. I., Lawrence, J. R., and Antweiler, R. C., 1979. Gypsum and halite from the Mid-Atlantic Ridge, DSDP Site 395. Earth Planet. Sci. Lett., 42:98-102.

Grinenko, V. A., Grinenko, L. N., and Zagryazhkaya, G. D., 1969. Kinetic isotope effects during high temperature sulfate reduction. Geokhimiya, 4:484-491.

Haymon, R., and Kastner, M., 1981. Hot springs deposits on the East Pacific Rise at $21^{\circ} \mathrm{N}$ : preliminary description and genesis. Earth Planet. Sci. Lett., 53:363-381.

Holt, B. D., and Engelkemeir, A. G., 1970. Thermal decomposition of barium sulfate to sulfur dioxide for mass spectrometric analysis. Anal. Chem., 42:1451-1453.

Leg 83 Scientific Party, in press. DSDP Hole 504B, the first reference section over $1 \mathrm{~km}$ through Layer 2 of the oceanic crust. Nature.

Mizutani, Y., 1971. An improvement in the carbon-reduction method for oxygen isotopic analysis of sulphates. Geochem. J., 5:69-77.

Mottl, M. J., 1976. Chemical exchange between seawater and basalt during hydrothermal alteration of the oceanic crust [Ph. D. dissert.]. Harvard Univ., Cambridge, Mass.

Ohmoto, H., and Lasaga, A. C., 1980. Kinetics of isotopic exchange and chemical reactions between sulfides and sulfates in hydrothermal solutions. Geol. Soc. Am. Abstracts with Programs, 12:494. (Abstract)

Rees, C. E., 1978. Sulphur isotope measurements using $\mathrm{SO}_{2}$ and $\mathrm{SF}_{6}$. Geochim. Cosmochim. Acta, 42:383-389.

Ricke, W., 1964. Präparation von Schwefeldioxyd zur massenspektrometrischen Bestimmung des Schwefel-Isotopen-Verhaltnisses ${ }^{32} \mathrm{~S} /$ ${ }^{34} \mathrm{~S}$ in Schwefelverbindungen. Z. Anal. Chem., 199:401-413.

Sakai, H., and Krouse, H. R., 1971. Elimination of memory effects in ${ }^{18} \mathrm{O} /{ }^{16} \mathrm{O}$ determinations in sulphates. Earth Planet Sci. Lett., 11: 369-373.

Shanks, W. C., Bischoff, J. L., and Rosenbauer, R. J., 1981. Seawater sulfate reduction and sulfur isotope fractionation in basaltic systems: Interaction of seawater with fayalite and magnetite at 200-350 ${ }^{\circ} \mathrm{C}$. Geochim. Cosmochim. Acta, 45:1977-1995.

Seyfried, W. E., 1977. Seawater-basalt interaction from $25^{\circ}-300^{\circ} \mathrm{C}$ and 1-500 bars: implications for the origin of submarine metal- 
bearing hydrothermal solutions and regulation of ocean chemistry [Ph. D. dissert.]. Univ. Calif., Los Angeles.

Seyfried, W. E., Jr., Mottl, M. J., and Bischoff, J. L., 1978. Seawater/basalt ratio effects on the chemistry and mineralogy of spilites from the ocean floor. Nature, 275:211-213.

Styrt, M. M., Brackmann, A. J., Holland, H. D., Clark, B. C., Pisutha-Arnond, V., Eldridge, C. S., and Ohmoto, H., 1981. The mineralogy and the isotopic composition of sulfur in hydrothermal sulfide/sulfate deposits on the East Pacific Rise, $21^{\circ} \mathrm{N}$ latitude. Earth Planet. Sci. Lett., 53:382-390.

Thode, H. G., and Rees, C. E., 1971. Measurement of sulphur concentrations and the isotope ratios ${ }^{33} \mathrm{~S} /{ }^{32} \mathrm{~S},{ }^{34} \mathrm{~S} /{ }^{32} \mathrm{~S}$ and ${ }^{36} \mathrm{~S} /{ }^{32} / \mathrm{S}$ in Apollo 12 samples. Earth Planet. Sci. Lett., 12:434-438.

Tómasson, J., and Kristmannsdottir, H., 1972. High temperature alteration minerals and thermal brines, Reykjanes, Iceland. Contrib. Mineral. Petrol., 36:123-134.

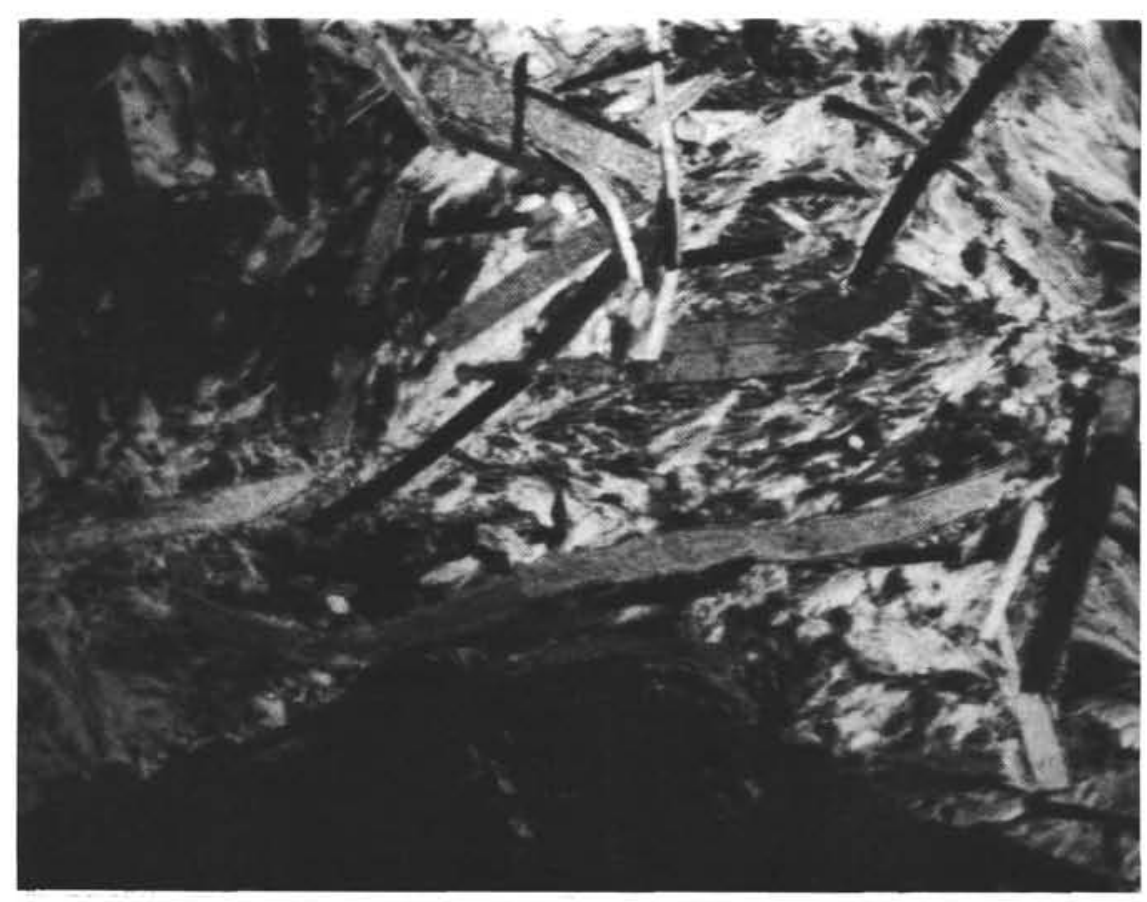

Plate 1. Photomicrograph of the anhydrite-bearing vein in Sample 504B-48-3 (14-18 cm). The large bladed anhydrite crystals (the longest is about $5 \mathrm{~mm}$ in length) are embedded in sheaflike aggregates of gyrolite fibers. The wall rock on the lower part of the photograph is lined with a smectite border overgrown with clear quartz prisms. 